Ördög A., Poór P., Štajner D., Popović B., Bátori Z., Tari I. 2018.

Comparison of the mineral content of processed spice samples of sweet and hot paprika from the Szeged region.

J. Elem., 23(2): 521-530. DOI: 10.5601/jelem.2017.22.4.1497

\title{
COMPARISON OF THE MINERAL CONTENT OF PROCESSED SPICE SAMPLES OF SWEET AND HOT PAPRIKA FROM THE SZEGED REGION*
}

\author{
Attila Ördög1, Péter Poór ${ }^{1}$, Dubravka Štajner², Boris Popović ${ }^{2}$, \\ Zoltán Bátori ${ }^{3}$, Irma Tari ${ }^{1}$ \\ ${ }^{1}$ Department of Plant Biology \\ University of Szeged, Hungary \\ ${ }^{2}$ Faculty of Agriculture \\ University of Novi Sad, Serbia \\ ${ }^{3}$ Department of Ecology \\ University of Szeged, Hungary
}

\begin{abstract}
Ground paprika is an important product of traditional agriculture in Hungary, which is used not only as a spice but also as a natural colour additive in cookery worldwide. There are two main types of paprika based on its pungency: sweet and hot peppers. The content of metals in paprika samples is essential for food safety and quality; in addition, it provides elemental fingerprints about the region where the pepper was produced. A multi-elemental analysis of sweet and hot paprika samples originating from the Szeged region, Hungary, and from Serbia was performed by inductively coupled plasma-mass spectrometry (ICP-MS), and their mineral composition was compared. It has been demonstrated by principal component analysis (PCA) that the samples containing the highest amounts of $\mathrm{K}, \mathrm{Mg}$, Mo and As were among hot paprika samples, while the lowest amounts of $\mathrm{Mg}, \mathrm{B}$ and $\mathrm{As}$ and the highest amounts of $\mathrm{Cu}$ were mostly found in sweet paprika. The pungent compound in hot pepper is capsaicin synthesized from valine and phenylalanine in placentas of hot pepper. Mo is a component of molybdopterin in nitrate reductase, $\mathrm{Mg}^{2+}$ is a metal cofactor of glutamine synthetase and acetolactate synthase, participating in ammonia assimilation and in biosynthesis of valine, respectively. Thus, these elements improve the nitrate assimilation and amino acid synthesis, as a result of which they can promote the biosynthesis of capsaicin and development of pungency. Moreover, a higher level of B can be used for the determination of geographical origin of Hungarian paprika.
\end{abstract}

Keywords: Capsicum annuum L. cv. longum, ground paprika samples, hot and sweet paprika, ICP-MS, macro- and microelement content.

Péter Poór, Department of Plant Biology, University of Szeged, Közép fasor 52, H-6726 Szeged, Hungary, tel./fax.: +36 62 544307, e-mail: poorpeti@bio.u-szeged.hu

* This work was supported by the Social Renewal Operational Programme (grant no. TÁMOP-4.1.1.C12/1/KONV-2012-0014) and by HUSRB/1203/221/173 "PLANTTRAIN" IPA Fund. 


\section{INTRODUCTION}

Ground paprika is made by grinding from air-dried pepper fruits of Capsicum annuum L. var. longum DC species (Codex Alimentarius Hungaricus 2-211), which is the most popular spice in Hungary. Various nutritional components, antioxidants, vitamins, carotenoids and phenolic compounds are also represented in paprika fruits (Howard et al. 2000, NAVARRo et al. 2006, Park et al. 2011, Emmanuel-Ikpeme et al. 2014, Mamedov et al. 2015).

There are different types of ground paprika based on its pungency, which can be grouped into two main types: sweet and hot peppers (Codex Alimentarius Hungaricus 2-211). Processed paprika powder is made from the pericarp of the pepper, but it contains other part of the fruit, seeds, placenta and some part of calyces and stalks (ANDREWs 1995).

The southern part of the Great Hungarian Plain and northern Serbia (Vojvodina), but especially the region of Szeged, are famous for their paprika production in Europe (Somos 1966, Kocsis et al. 2002). Moreover, paprika from the Szeged region is assigned the status of Protected Designation of Origin (PDO) by the European Commission of Agriculture and Rural Development (European Council Regulation No. 510/2006, 2006). Accordingly, the quality of this product is of great economic importance in this region, which is determined by the geographic origin. Mineral composition is an important marker of the quality and gives elemental fingerprints of regional agricultural products (BRUNNer et al. 2010). Moreover, metal constituents of spices and herbal plants have important positive or negative roles in human life (KARADAS, KARA 2012). The metal content in pepper fruit can be influenced by different factors, such as the concentrations of these elements in the soil, fertilizing practices and processing conditions (PALAcios-Morillo et al. 2014). For this reason, the characterization and determination of the elemental content in paprika are important in plant biology and food science. However, no comparison of the mineral composition of sweet and hot peppers from Hungary has been performed so far.

The pungent compounds in hot pepper are capsaicinoids (CAPs), which are synthesized from nitrogenous compounds derived from valine (Val) and phenylalanine (Phe) by acetolactate synthase (ALS) and arogenate dehydratase (ADT) enzymes exclusively in placentas of the hot pepper (BAAS-ESPINOLA et al. 2016). Moreover, the increase in nitrate availability in placental tissues (AlDANA-IUIT et al. 2015) or the activation of glutamine synthetase/glutamate synthase cycle (GS/GOGAT cycle) resulted in CAP accumulation (BAAS-ESPINOLA et al. 2016). Since ALS and GS require $\mathrm{Mg}^{2+}$ as a metal cofactor, while nitrate reductase contains Mo in the form of molybdopterin, a need for specific metal ions to develop pungency in hot pepper can be suggested.

The main objectives of this work were to determine the mineral content of red ground paprika samples collected from the Szeged region in Hungary and Serbia. Accordingly, the levels of macro-, micro- and toxic elements were 
determined and compared between different sweet and hot paprika samples ground by small factories or by farmers, in oder to assess the quality, safety and nutritional value of paprika samples. We were also interested in whether the metal ions necessary for CAP biosynthesis would accumulate in processed hot pepper samples.

\section{MATERIAL AND METHODS}

\section{Growing conditions of pepper and the origin of samples}

Paprika samples were collected in 2013 and 2014 from the Szeged region (Figure 1). Samples were taken directly from farmers (Hungary: $n=12$; Serbia: $n=4)$. Pepper plants were grown in fields on private farms, and were exposed to natural light, temperature, soil moisture and meteorological conditions. Fruits at harvesting maturity were used to make each of the tested dried sample. Soils in the Szeged region are mostly chernozem and meadow soils (BLAsKó 2008). The investigated area has a continental climate and may be characterized with hot summers. In warm years, the mean annual temp.

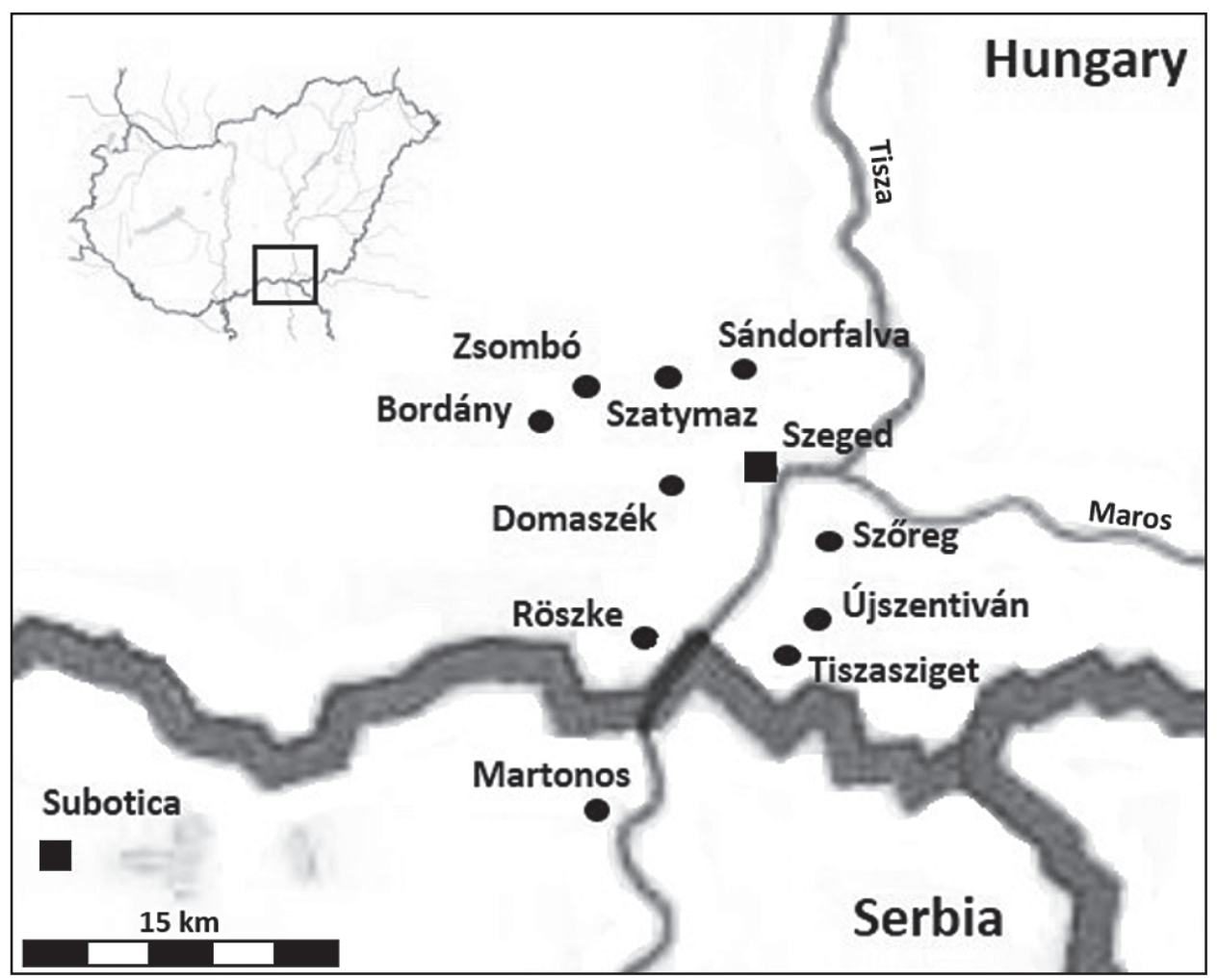

Fig. 1. Location of the sampling sites in Hungary and Serbia 
is above $11.5^{\circ} \mathrm{C}$ and the mean temp. in July is above $22^{\circ} \mathrm{C}$ with a dry period in middle summer (Mezősi, Szathmári 1998). All samples were purchased as ground powder and were analysed no more than three months after spice processing. Samples were stored in tubes and kept in the dark. The declared botanical origin by the producers was considered.

\section{Determination of the elements}

Concentration of mineral elements was determined by XSeries II Inductively Coupled Plasma-Mass Spectrometry (ICP-MS; Thermo Scientific, Bremen, Germany). $100 \mathrm{mg}$ of each paprika sample was homogenized and placed in test tubes for $20 \mathrm{~h}$, which contained $6 \mathrm{ml}$ concentrated nitric acid $\left(\mathrm{HNO}_{3}\right)$ and $2 \mathrm{ml} \mathrm{H}_{2} \mathrm{O}_{2}$. The samples were digested in MarsXpress microwave destructor system (CEM, Matthews NC, USA) at $200^{\circ} \mathrm{C}$ for $25 \mathrm{~min}(1600 \mathrm{~W})$. Then they were cooled and diluted with $12 \mathrm{ml}$ double-distilled water before the measuring (ÖRDÖG et al. 2017). All measurements were carried out at least three times.

\section{Statistical analysis}

The presence of significant differences between data means was determined by Student's $t$-test at $P \leq 0.05$ significance level, using the Sigma plot 11.0 software (Systat Software Inc., Erkrath, Germany). Principal component analysis (PCA) was conducted with PAST 3.05 program (JoLLIFFE 2002).

\section{RESULTS AND DISCUSSION}

\section{Differences in mineral content}

The mineral content of the studied sweet and hot paprika samples is shown in Table 1. Potassium was the most abundant metal ion in all pepper samples. The $\mathrm{K}$ concentration ranged from 27.37 to $35.05 \mathrm{~g} \mathrm{~kg}^{-1}$ dry mass (d.m.) in hot paprika, while the average was $31.46 \mathrm{~g} \mathrm{~kg}^{-1} \mathrm{~d} . \mathrm{m}$., which was significantly higher compared to the potassium content of sweet paprika (29.73 $\mathrm{g} \mathrm{kg}^{-1} \mathrm{~d}$.m.) from Szeged region. Similar values ( $30 \mathrm{~g} \mathrm{~kg}^{-1} \mathrm{~d} . \mathrm{m}$.) of K content were found in the fruits of two sweet pepper genotypes from Russia (MAMEDOv et al. 2015), in a traditional Spanish pepper variety (BERNARDo et al. 2008) and in sweet paprika fruit from Nigeria (EMMANUEL-IKPEME et al. 2014). Moreover, the $\mathrm{K}$ concentration was lower than in the Hungarian sweet papri$\mathrm{ka}$ in red and green pepper fruits from Tenerife, Canary Islands (RUBIo et al. 2002) and in seven investigated sweet pepper cultivars from Poland (JADCZAK et al. 2010). However, there were no significant differences between medians of $\mathrm{K}$ contents in processed samples of sweet- and hot paprika originated in two regions, in Murcía and Extremadura, Spain (PALAcios-Morillo et al. 2014), but total $\mathrm{K}$ contents were the lowest values (9.169-20.158 $\mathrm{g} \mathrm{kg}^{-1} \mathrm{~d} . \mathrm{m}$.) among the previously cited articles. 
Average elemental content of red paprika samples from the Szeged region (2013 and 2014)

\begin{tabular}{|c|c|c|}
\hline \multirow{2}{*}{ Parameter } & \multicolumn{2}{|c|}{ Paprika types } \\
\hline & sweet $(n=16)$ & $\operatorname{hot}(n=16)$ \\
\hline $\begin{array}{l}\mathbf{K}\left(\mathrm{g} \mathrm{kg}^{-1} \text { d.m. }\right) \\
\text { mean } \pm \mathrm{SD} \\
\text { range }\end{array}$ & $\begin{array}{c}29.73^{B} \pm 2.82 \\
25.01-33.67\end{array}$ & $\begin{array}{l}31.46^{A} \pm 2.26 \\
27.37-35.05\end{array}$ \\
\hline $\begin{array}{l}\mathbf{M g}\left(\mathrm{g} \mathrm{kg}^{-1} \mathrm{~d} . \mathrm{m} .\right) \\
\text { mean } \pm \mathrm{SD} \\
\text { range }\end{array}$ & $\begin{array}{r}2.13^{B} \pm 0.29 \\
1.63-2.84\end{array}$ & $\begin{array}{c}2.41^{A} \pm 0.22 \\
2.02-2.81\end{array}$ \\
\hline $\begin{array}{c}\mathbf{F e}\left(\mathrm{mg} \mathrm{kg}^{-1} \mathrm{~d} . \mathrm{m} .\right) \\
\text { mean } \pm \mathrm{SD} \\
\text { range }\end{array}$ & $\begin{array}{r}145.66^{\mathrm{NS}} \pm 54.84 \\
71.17-267.93\end{array}$ & $\begin{array}{r}148.24^{\mathrm{NS}} \pm 43.78 \\
95.70-250.87\end{array}$ \\
\hline $\begin{array}{c}\mathrm{Zn}\left(\mathrm{mg} \mathrm{kg}^{-1} \text { d.m. }\right) \\
\text { mean } \pm \mathrm{SD} \\
\text { range }\end{array}$ & $\begin{array}{l}24.41^{\mathrm{NS}} \pm 4.84 \\
\quad 15.45-32.14\end{array}$ & $\begin{array}{r}23.29^{\mathrm{NS}} \pm 3.15 \\
17.92-28.59\end{array}$ \\
\hline $\begin{array}{r}\mathbf{C u}\left(\mathrm{mg} \mathrm{kg}^{-1} \text { d.m. }\right) \\
\text { mean } \pm \mathrm{SD} \\
\text { range }\end{array}$ & $\begin{array}{r}21.83^{\mathrm{NS}} \pm 4.39 \\
12.59-26.46\end{array}$ & $\begin{array}{r}22.20^{\mathrm{NS}} \pm 1.77 \\
19.05-25.84\end{array}$ \\
\hline $\begin{array}{c}\text { Mn (mg kg.-1 d.m.) } \\
\text { mean } \pm \mathrm{SD} \\
\text { range }\end{array}$ & $\begin{array}{r}16.26^{\mathrm{NS}} \pm 3.57 \\
9.05-23.37\end{array}$ & $\begin{aligned} 16.85^{\mathrm{NS}} & \pm 2.57 \\
14.26 & -23.07\end{aligned}$ \\
\hline $\begin{array}{c}\mathbf{B}\left(\mathrm{mg} \mathrm{kg}^{-1} \text { d.m. }\right) \\
\text { mean } \pm \mathrm{SD} \\
\text { range }\end{array}$ & $\begin{aligned} & 40.95^{B} \pm 8.09 \\
& 20.80-46.66\end{aligned}$ & $\begin{array}{r}45.03^{A} \pm 2.33 \\
40.94-51.41\end{array}$ \\
\hline $\begin{array}{r}\mathrm{Al}\left(\mathrm{mg} \mathrm{kg}^{-1} \mathrm{~d} . \mathrm{m} .\right) \\
\text { mean } \pm \mathrm{SD} \\
\text { range }\end{array}$ & $\begin{array}{r}215.45^{\mathrm{NS}} \pm 115.50 \\
66.39-433.55\end{array}$ & $\begin{array}{c}205.70^{\mathrm{NS}} \pm 61.19 \\
138.20-341.90\end{array}$ \\
\hline $\begin{array}{c}\text { Co }\left(\mu \mathrm{g} \mathrm{kg}^{-1} \mathrm{~d} . \mathrm{m} .\right) \\
\text { mean } \pm \mathrm{SD} \\
\text { range }\end{array}$ & $\begin{array}{l}342.47^{\mathrm{NS}} \pm 95.63 \\
221.03-573.30\end{array}$ & $\begin{array}{r}344.51^{\mathrm{NS}} \pm 152.03 \\
173.70-694.73\end{array}$ \\
\hline $\begin{array}{l}\mathrm{Ni}\left(\mu \mathrm{g} \mathrm{kg}^{-1} \text { d.m. }\right) \\
\text { mean } \pm \mathrm{SD} \\
\text { range }\end{array}$ & $\begin{array}{r}1657.63^{\mathrm{NS}} \pm 695.59 \\
670.50-3119.00\end{array}$ & $\begin{array}{r}1606.51^{\mathrm{NS}} \pm 1081.39 \\
508.20-3678.00\end{array}$ \\
\hline $\begin{array}{r}\mathrm{Se}\left(\mu \mathrm{g} \mathrm{kg}{ }^{-1} \text { d.m. }\right) \\
\text { mean } \pm \mathrm{SD} \\
\text { range }\end{array}$ & $\begin{array}{r}708.00^{\mathrm{NS}} \pm 281.03 \\
228.23-1099.50\end{array}$ & $\begin{array}{r}692.30^{\mathrm{NS}} \pm 340.11 \\
117.43-1440.00\end{array}$ \\
\hline $\begin{array}{c}\text { Mo }(\mu \mathrm{g} \mathrm{kg-1} \text { d.m. }) \\
\text { mean } \pm \mathrm{SD} \\
\text { range }\end{array}$ & $\begin{array}{r}339.63^{B} \pm 146.59 \\
101.83-667.23\end{array}$ & $\begin{array}{c}447.73^{A} \pm 201.19 \\
171.73-987.90\end{array}$ \\
\hline $\begin{array}{c}\text { As }\left(\mu \mathrm{kg}^{-1} \text { d.m. }\right) \\
\text { mean } \pm \mathrm{SD} \\
\text { range }\end{array}$ & $\begin{array}{r}52.06^{B} \pm 16.05 \\
24.44-77.54\end{array}$ & $\begin{array}{r}67.14^{A} \pm 11.23 \\
45.70-89.23\end{array}$ \\
\hline $\begin{array}{c}\mathrm{Pb}\left(\mu \mathrm{g} \mathrm{kg}{ }^{-1} \text { d.m. }\right) \\
\text { mean } \pm \mathrm{SD} \\
\text { range }\end{array}$ & $\begin{array}{r}164.45^{\mathrm{NS}} \pm 52.10 \\
84.01-258.73\end{array}$ & $\begin{array}{r}158.67^{\mathrm{NS}} \pm 54.29 \\
70.63-267.90\end{array}$ \\
\hline $\begin{array}{r}\mathbf{C d}\left(\mu \mathrm{g} \mathrm{kg}^{-1} \text { d.m. }\right) \\
\text { mean } \pm \mathrm{SD} \\
\text { range }\end{array}$ & $\begin{array}{r}75.41^{\mathrm{NS}} \pm 40.61 \\
19.88-163.73\end{array}$ & $\begin{array}{r}91.41^{\mathrm{NS}} \pm 56.76 \\
22.41-201.25\end{array}$ \\
\hline
\end{tabular}

The number of samples of each paprika type (n) is given in parentheses; SD - Standard error of the mean; Means denoted by different letters indicate significant differences at the 0.05 level (Student's $t$-test); NS - not significant. 
The $\mathrm{Mg}$ concentration ranged from $2.02-2.81 \mathrm{~g} \mathrm{~kg}^{-1} \mathrm{~d}$.m. and the average values were significantly higher in hot paprika samples $\left(2.41 \mathrm{~g} \mathrm{~kg}^{-1} \mathrm{~d} . \mathrm{m}\right.$.) compared to sweet paprika (2.13 $\mathrm{g} \mathrm{kg}^{-1} \mathrm{~d}$.m.). In accordance with our results, Palacios-Morillo and co-workers (2014) found similar Mg content in hot paprika samples, which was higher than in sweet paprika samples derived from Murcia. However, the fruits of sweet paprika cultivars originating from Spain (Bernardo et al. 2007), Tenerife (Rubio et al. 2002) and Poland (JADCZAK et al. 2010) contained much lower Mg levels (0.87-1.6 g kg-1 d.m.) $\mathrm{Mg}$. Since $\mathrm{Mg}^{2+}$ is a metal cofactor of GS and ALS, its high availability and accumulation in hot pepper may contribute to enhanced primary nitrogen metabolism and to the synthesis of CAP precursor Val in pungent genotypes.

Both the B and Mo content showed significant differences between sweet and hot pepper in the processed spice samples. The B concentration was significantly higher in hot paprika (45.03 $\mathrm{mg} \mathrm{kg}^{-1} \mathrm{~d} . \mathrm{m}$.) compared to the sweet paprika samples (40.95 $\mathrm{mg} \mathrm{kg}^{-1}$ d.m.). The B content was lower than obtained in our research in several European paprika samples, including other Hungarian paprika (BRUNNER et al. 2010), and in sweet and hot paprika types from Spain (PALACIOS-Morillo et al. 2014). B is an essential microelement for plants, which plays a role in the control of cell division, seed and fruit development, pollen tube elongation and sugar transport, thus a high boron content helps to grow healthy fruits. The majority of water soluble boron seems to be localized in the apoplastic region as boric acid. The water insoluble B is associated with the rhamnogalacturonan II (RG-II) fraction of the cell wall matrix. Changes in cell wall components are associated with different phases of fruit ripening. Accumulation of CAPs displayed an inverse relationship with the lignin content of the cell wall of pepper fruit (ESTRADA et al. 2000). The authors detected maximal levels of lignin in early stages of fruit development, followed by a decrease, which coincided with the softening of the pericarp and accumulation of CAP in placentas. Thus softening may supply phenolic substrates for phenylpropanoid and capsaicin biosynthesis, which occurs in parallel with the chemical restructuring of the cell wall. The B-containing RG-II fraction of the cell wall may be an important player in this process.

We found that the Mo content of Hungarian hot paprika $\left(447.73 \mu \mathrm{g} \mathrm{kg}^{-1}\right.$ d.m.) was significantly higher than that of the sweet, delicate paprika (339.63 $\mu \mathrm{g} \mathrm{kg}^{-1}$ d.m.) samples. High Mo content may also favour the pungency of pepper because it is a metal cofactor of nitrate reductase in the form of molybdopterin. Availability of nitrate and nitrate reduction is also a limiting factor for the biosynthesis of CAP, thus it can contribute to the development of flavour.

In contrast, we did not find significant differences between the sweet and hot paprika considering their Fe (71.17-267.93 $\left.\mathrm{mg} \mathrm{kg}^{-1}\right)$, Zn (15.45-32.14 $\left.\mathrm{mg} \mathrm{kg}^{-1}\right)$, $\mathrm{Cu}\left(12.59-26.46 \mathrm{mg} \mathrm{kg}^{-1}\right), \mathrm{Mn}\left(9.05-23.37 \mathrm{mg} \mathrm{kg}^{-1}\right), \mathrm{Al}\left(66.39-433.55 \mathrm{mg} \mathrm{kg}^{-1}\right)$, Co (173.70-694.73 $\left.\mu \mathrm{g} \mathrm{g}^{-1}\right)$, Ni (508.20-3678.00 $\left.\mathrm{g} \mathrm{kg}^{-1}\right)$ and Se (117.43-1440.00 $\mu \mathrm{g}$ $\left.\mathrm{kg}^{-1}\right)$ content on a dry mass basis. 
Comparing our data with the literature, a higher Fe content was observed in chili pepper fruits from Turkey than in our samples (KARADAS, KarA 2012) and sweet pepper fruits from Poland (JADCZAK et al. 2010). A lower Fe content was measured in the fruit of other sweet pepper genotypes from Poland (Buczkowska et al. 2015) and Spain (Bernardo et al. 2008), but Fe levels were in a similar range as our in samples in the processed Spanish peppers (Palacios-Morillo et al. 2014).

The Zn content of investigated Spanish sweet paprika samples was significantly higher than in hot paprika (PALACIOS-MorILLO et al. 2014) and it varied from 11,3 to $33,4 \mu \mathrm{g} \mathrm{g}^{-1} \mathrm{~d}$.m. in the processed samples of European, African and Asian origin (BRUNnER et al. 2010).

The $\mathrm{Cu}$ and $\mathrm{Al}$ content was lower than in the Hungarian samples in processed paprika from Spain (PALACIOs-Morillo et al. 2014) and in other countries. Interestingly, the $\mathrm{Al}$ content was extremely high in a Chinese paprika sample (BRUNNER et al. 2010).

Higher Mn content was found in both paprika types from Spain (PALACIOS-MoriLlo et al. 2014) and in paprika samples originating from other countries in Europe (BRUNnER et al. 2010), whereas Co concentration exceeded the level found in most samples originating from the Szeged region, from other European countries and from China.

Higher Ni content was detected in Turkish paprika fruits (KARADAS, KARA 2012), while it was lower in Russian genotypes (MAMEDov et al. 2015) and ground sweet and hot paprika samples from Spain (PALACIOs-Morillo et al. 2014) compared to the Hungarian results.

The investigated Hungarian paprika samples contained only very small amounts of toxic elements ( $\mathrm{As}, \mathrm{Pb}$ and $\mathrm{Cd}$ ), but a higher $\mathrm{As}$ content was measured in hot $\left(67.14 \mu \mathrm{g} \mathrm{kg} \mathrm{kg}^{-1} \mathrm{~d} . \mathrm{m}\right.$.) than in sweet ground paprika (52.06 $\mu \mathrm{g} \mathrm{kg}{ }^{-1}$ d.m.). Similar As and Cd values were found in Turkish sweet red pepper (KARADAS, KARA 2012), but they were lower in Russian sweet pepper fruits (Mamedov et al. 2015). Palacios-Morillo and co-workers (2014) revealed a higher content of $\mathrm{Pb}$ in Spanish paprika samples compared to our results (70.63-267.90 $\mu \mathrm{g} \mathrm{kg}^{-1}$ d.m.). It has to be emphasized that concentrations of toxic elements were below the legal threshold limit in foodstuff.

\section{Multivariate analysis of samples}

PCA did not show a clear separation between the hot and sweet paprika samples (Figure 2). The first PCA axis explained 25\%, the second PCA axis $18 \%$ of the variance of the elemental content. Two sweet paprika samples ('Röszke' and 'Szatymaz') were at the lower end of PCA axis 1, with a relatively low content of $\mathrm{Al}, \mathrm{B}, \mathrm{Cu}, \mathrm{Fe}$ and $\mathrm{Mn}$, while, at the higher end, there was one (cv. Tiszasziget) with a relatively high content of these elements. Samples containing the lowest amounts of $\mathrm{Mg}, \mathrm{B}$ and $\mathrm{As}$ and the highest amounts of $\mathrm{Cu}$ were mostly found among the sweet paprika samples, while samples containing the highest amounts of $\mathrm{K}, \mathrm{Mg}$, Mo and As were among 


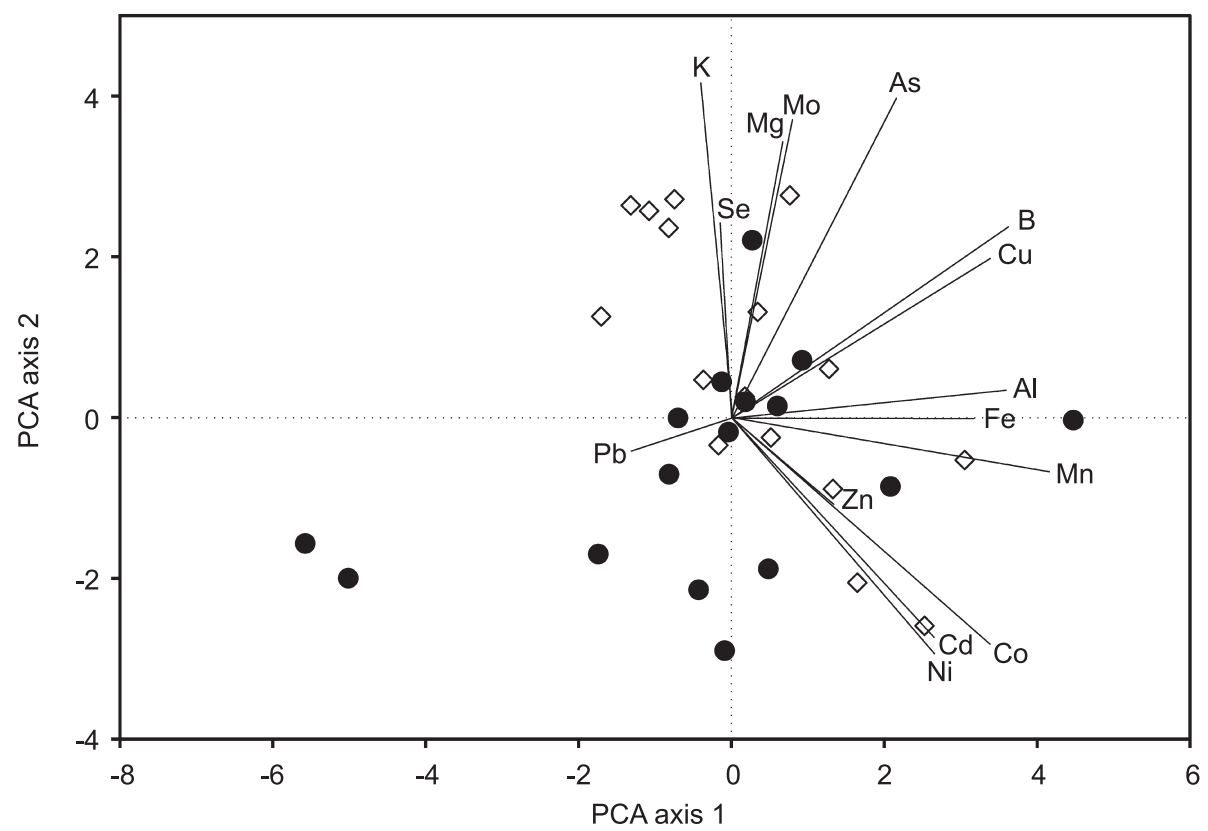

Fig. 2. Biplot ordination diagram of the first two PCA axes with paprika samples (white diamond: hot; black circle: sweet) and elements (Al-Zn). Percentage of variance explained by the PCA axis 1 and PCA axis 2 is $25 \%$ and $18 \%$, respectively.

The number of samples of each paprika type is 16

hot paprika samples. Interestingly, $\mathrm{Mg}$ and Mo proved to be important metal cofactors of enzymes participating in primary $\mathrm{N}$ metabolism. Mo is a metal component of molybdopterin in nitrate reductase, $\mathrm{Mg}^{2+}$ is a metal cofactor of GS and ALS, the latter participates in biosynthesis of Val amino acid. These elements improve the nitrate assimilation and amino acid synthesis, hence they can promote the biosynthesis of capsaicin. It is very interesting that their accumulation is closely, although not exclusively, coupled to the development of pungency. Increases in B concentrations promote the fruit setting and the development of fruits, but above all, they can affect cell wall softening and they can improve fruit quality of hot pepper during ripening.

\section{CONCLUSIONS}

The results obtained from the elemental analysis showed that there are differences in major, trace and toxic elements between sweet and hot paprika samples originated from the Szeged region, which can be used for quality assessment. We can conclude that the investigated paprika types were of good quality and contained only very small amounts of toxic elements (As, 
$\mathrm{Pb}$ and $\mathrm{Cd}$ ). The most abundant metal in paprika samples was $\mathrm{K}$, followed by $\mathrm{Mg}, \mathrm{Al}, \mathrm{Fe}, \mathrm{B}, \mathrm{Zn}, \mathrm{Cu}$ and $\mathrm{Mn}$. However, hot paprika contained significantly higher $\mathrm{K}, \mathrm{Mg}, \mathrm{B}$ and Mo than sweet paprika, which can contribute to the synthesis of capsaicin and therefore, promote the development of pungency, an important quality marker of this paprika type. Moreover, compared to international data, Hungarian paprika samples contain mostly similar trace element values that can be found in the samples from Turkey or Spain, except of the higher level of $\mathrm{B}$, which can be used for the determination of geographical origin of paprika.

\section{ACKNOWLEDGEMENTS}

We gratefully thank the producers for providing paprika samples, and Erzsébet Porkoláb for her excellent technical assistance.

This work was supported by the Social Renewal Operational Programme (grant no. TÁMOP-4.1.1.C-12/1/KONV-2012-0014) and by HUSRB/1203/221/173 "PLANTTRAIN" IPA Fund.

\section{REFERENCES}

Andrews J. 1995. Peppers: the domesticated Capsicums. University of Texas Press.

Aldana-Iuit J.G., Sauri-Duch E., Miranda-Ham M.D.L., Castro-Concha L.A., Cuevas-Glory L.F., VÁzquez-Flota F.A. 2015. Nitrate promotes capsaicin accumulation in capsicum chinense immobilized placentas. BioMed. Res. Int., 2015, ID 794084; http://dx.doi.org/10.1155/2015/ 794084 .

BLASKó L. 2008. Soil Science. TAMOP 4.2.5 Book Database (In Hungarian) http://www.tankonyvtar.hu/ en/tartalom/tamop425/0032_talajtan/ch12.html (last accessed 10 October 2017)

Baas-Espinola F.M., Castro-Concha L.A., Vázquez-Flota F.A., Miranda-Ham M.L. 2016. Capsaicin synthesis requires in situ phenylalanine and valine formation in in vitro maintained placentas from capsicum chinense. Molecules, 21(6): 799. DOI: 10.3390/molecules21060799

Bernardo A.N.A., Martinez S., Alvarez M., Fernández A.N.A., Lopez M. 2008. The composition of two Spanish pepper varieties (Fresno de la Vega and Benavante-Los Valles) in different ripening stages. J. Food Qual., 31(6): 701-716.

Brunner M., Katona R., Stefánka Z., Prohaska T. 2010. Determination of the geographical origin of processed spice using multielement and isotopic pattern on the example of Szegedi paprika. Eur. Food Res. Technol., 231(4): 623-634.

Buczkowska H., Michąojć Z., Konopińska J., Kowalik P. 2015. Content of macro- and microelements in sweet pepper fruits depending on foliar feeding with calcium. J. Elem., 20(2): 261-272.

Codex Alimentarius Hungaricus 2-211 Ground paprika 2013. Available at http://www.omgk.hu/ Mekv/2/2-108.pdf (last accessed 12 July 2017)

Emmanuel-Ikpeme C., Henry P., Okiri O.A. 2014. Comparative evaluation of the nutritional, phytochemical and microbiological quality of three pepper varieties. J. Food Nutr. Sci., 2(3): 74-80.

Estrada B., Bernal M. A., Díaz J., Pomar F., Merino F. 2000. Fruit development in Capsicum annuum: Changes in capsaicin, lignin, free phenolics, and peroxidase patterns. J. Agric. Food Chem., 48(12): 6234-6239.

European Council Regulation No 510/2006 2006. Official Journal of the European Union, European Commission, Brussels, Available at http://eur-lex.europa.eu/legal-content/EN/TXT/ PDF/?uri=CELEX:32006R0510\&from=EN (last accessed 12 July 2017) 
Howard L. R., Talcott S. T., Brenes C. H., Villalon B. 2000. Changes in phytochemical and antioxidant activity of selected pepper cultivars (Capsicum species) as influenced by maturity. J. Agric. Food. Chem., 48: 1713-1720.

JaDCZAK D., Grzeszczuk M., Kosecka D. 2010. Quality characteristics and content of mineral compounds in fruit of some cultivars of sweet pepper (Capsicum annuum L). J. Elem., 15(3): 509-515.

Jolliffe I. 2002. Principal Component Analysis. Springer, New York $2^{\text {nd }}$ edition

Karadas C., KarA D. 2012. Chemometric approach to evaluate trace metal concentrations in some spices and herbs. Food Chem., 130(1): 196-202.

Kocsis N., Amtmann M., Mednyánszky Z., Korány K. 2002. GC-MS Investigation of the aroma compounds of Hungarian red paprika (Capsicum annuum) cultivars. J. Food Comp. Anal., 15(2): 195-203.

Mamedov M.I., Pyshnaya O.N., Dzhos Y.A., Matyukina A.A., Golubkina N.A., Nadezhkin S.M., Pivovarov V.F. 2015. Quality characteristics of paprika pepper varieties (Capsicum annum L) under Moscow Oblast conditions. Russ. Agric. Sci., 41(5): 326-330.

Mezősi G., Szathmári J. 1998. Assessment of wind erosion risk on the agricultural area of the southern part of Hungary. J. Hazard. Mat., 61(1-3): 139-153.

Navarro J.M., Flores P., Garrido C., Martinez V. 2006. Changes in the contents of antioxidant compounds in pepper fruits at different ripening stages, as affected by salinity. Food Chem., 96: 66-73.

Ördög A., TARi I., BÁtori Z., PoóR P. 2017. Mineral content analysis of unifloral honeys from the Hungarian Great Plain. J. Elem., 22(1): 271-281.

Palacios-Morillo A., Jurado J.M., Alcázar Á., de Pablos F. 2014. Geographical characterization of Spanish PDO paprika by multivariate analysis of multielemental content. Talanta, 128: $15-22$.

PARK J., Kim S., Moon B. 2011. Changes in carotenoids, ascorbic acids, and quality characteristics by the pickling of paprika (Capsicum annuum L) cultivated in Korea. J. Food Sci., 76: C1075-C1080.

Rubio C., Hardisson A., Martín R.E., Báez A., Martín M.M., Álvarez R. 2002. Mineral composition of the red and green pepper (Capsicum annuum) from Tenerife Island. Eur. Food Res. Technol., 214(6): 501-504.

Somos A. 1966. A paprika. Akadémiai Kiadó, Budapest (in Hungarian) 